IMPLEMENTATION OF PHARMACEUTICAL SERVICED STANDARS AT KIMIA

FARMA PHARMACY IN KOTAMOBAGU CITY

\title{
PENERAPAN STANDAR PELAYANAN KEFARMASIAN PADA APOTEK KIMIA FARMA DI KOTA KOTAMOBAGU
}

\author{
Harmita Boky ${ }^{1 *}$, Widya Astuty Lolo ${ }^{1)}$, Imam Jayanto ${ }^{1)}$ \\ ${ }^{1)}$ Program Studi Farmasi FMIPA UNSRAT Manado, 95115 \\ *17101105055@student.unsrat.ac.id
}

\begin{abstract}
Pharmaceutical serviced have an important role in creating quality health to improve the quality of life of patients. The research purposed to measure the percentage of compliance wit the implementation of pharmaceutical serviced at Kimia Farma Pharmacy in Kotamobagu City, based on the Regulation of the Indonesia minister of health regulation Number 73/2016. This research used quantitative method with descriptive approach. The population in this study were all Kimia Farma Pharmacy in Kotamobagu City. The sampling technique used was saturated sampling Data were obtained through observation and filling out questionnaires. Based on the research results, it is known that the resource management of Pharmacy A, B, C has a percentage of $96 \%$ and Pharmacy D of $92 \%$. The percentage of pharmaceutical services at Pharmacy $A$ and $C$ is $100 \%$, Pharmacy $B$ is $97 \%$ and Pharmacy $D$ is $87 \%$. Based on the research results, it is known that all Kimia Farma pharmacies in Kotamobagu City are categorized as good, including the aspects of resource management and clinical pharmacy services.
\end{abstract}

Keywords : Pharmacy, Pharmacist, Pharmaceutical Service Standards

\begin{abstract}
ABSTRAK
Pelayanan kefarmasian berperan penting dalam mewujudkan kesehatan yang bermutu untuk meningkatkan kualitas hidup pasien. Penelitian ini bertujuan untuk mengukur persentase kesesuaian penerapan standar pelayanan kefarmasian di Apotek Kimia Farma di Kota Kotamobagu berdasarkan Peraturan Menteri Kesehatan Rupublik Indonesia Nomor 73 Tahun 2016. Penelitian ini merupakan jenis penelitian deskriptif. Populasi dalam penelitian ini ialah seluruh Apotek Kimia Farma di Kota Kotamobagu.Teknik pengambilan sampel yang digunakan adalah sampling jenuh. Pengambilan data melalui observasi langsung dan pengisian kuesioner. Berdasarkan hasil penelitian, diketahui pengelolaan sumber daya Apotek A, B, C memiliki persentase sebesar $96 \%$ dan Apotek D sebesar $92 \%$. Persentase pelayanan kefarmasian pada Apotek A dan C sebesar 100\%, Apotek B sebesar $97 \%$ dan Apotek D sebesar $87 \%$. Berdasarkan hasil penelitian ini diketahui bahwa seluruh apotek Kimia Farma di Kota Kotamobagu dikategorikan baik yang meliputi aspek pengelolaan sumber daya dan pelayanan farmasi klinik.
\end{abstract}

Kata kunci : Apotek, Apoteker, Standar Pelayanan Kefarmasian 


\section{PENDAHULUAN}

Pelayanan kesehatan adalah setiap upaya yang diselenggarakan secara sendiri atau bersamasama dalam suatu organisasi untuk memelihara dan meningkatkan kesehatan, mencegah dan menyembuhkan penyakit serta memulihkan kesehatan perorangan, keluaraga, kelompok dan atau masyarakat (Supardi, 2019).

Standar pelayanan kefarmasi terdiri dari 2 kegiatan utama yaitu pelayanan kefarmasian dan pengelolaan Sumber daya. Dalam menjalankan pekerjaan kefarmasian, apotek harus menerapkan standar pelayanan kefarmasian yang berlaku. Fasilitas pelayanan kefarmasian adalah sarana yang di gunakan untuk menyelenggarakan pelayanan kefarmasian, salah satunya adalah apotek (Anief,2001).

Standar Pelayanan Kefarmasian di Apotek, merupakan dasar dalam penyelenggaraan pelayanan di apotek. Apoteker memiliki tanggung jawab penuh dalam memberikan informasi obat kepada masyarakat . Kendala yang dihadapi dalam pelayanan kefarmasian di apotek adalah kompetensi dari tenaga farmasi itu sendiri, terutama pengetahuan mengenai peraturan perundang-undangan kefarmasian yang berlaku (Wintariani, 2017).

Penelitian yang dilakukan oleh Adelina (2010) menunjukan hasil bahwa penerapan Standar Pelayanan Kefarmasian di Apotek masih dalam kategori kurang dengan persentase sebesar $42,74 \%$. Melihat hal tersebut, maka peneliti tertarik untuk mengetahui kesesuaian pelaksanaan standar pelayanan kefarmasian di apotek menurut Peraturan Menteri Kesehatan Republik Indonesia Nomor 73 Tahun 2016 Tentang Standar Pelayanan Kefarmasian di Apotek (Permenkes RI, 2016).

Pelayanan kefarmasian memiliki peranan penting dalam mewujudkan kesehatan bermutu yang bertujuan untuk meningkatkan kualitas hidup pasien, sehingga perlu dilakukan penelitian. Berdasarkan latar belakang ini sehingga peneliti tertarik untuk melakukan penelitian tentang Penerapan Standar Pelayanan Kefarmasian di Apotek Kimia Farma di Kota Kotamobagu. Peneliti akan melakukan penelitian di apotek Kimia Farma Ahmad sebagai apotek A, Kimia Farma Sinindian Kotamobagu sebagai apotek B, Kimia Farma Mogolaing Kotamobagu sebagai apotek C, dan Kimia Farma Motoboi Kecil sebagai apotek D.

\section{METODOLOGI PENELITIAN \\ Waktu dan Tempat Penelitian}

Penelitian ini dilaksanakan pada bulan November 2020 - Februari 2021 di Apotek Kimia Farma di Kota Kotamobagu.

\section{Jenis Penelitian}

Penelitian ini merupakan jenis penelitian deskriptif. Penelitian deskriptif merupakan penelitian yang dilakukan dengan tujuan utama yaitu membuat gambaran atau deskripsi tentang suatu keadaan secara obyektif.

\section{Populasi dan Sampel}

Populasi dalam penelitian ini ialah seluruh Apotek Kimia Farma di Kota Kotamobagu. Teknik pengambilan sampel yang digunakan adalah sampling jenuh. Maka sampel yang diteliti sebanyak 4 Apotek yaitu Apotek Kimia Farma Mogolaing, Apotek Kimia Farma Ahmad Yani, Apotek Kimia Farma Motoboi Kecil dan Apotek Kimia Farma Sinindian.

\section{Alat dan Bahan}

Alat

Alat yang di gunakanan dalam penelitian yaitu kuesioner.

\section{Bahan}

Bahan yang di gunakan yaitu data apoteker, pengelolaan sumber daya apotek,pelayanan kefarmasian dan bahan ini nantinya termuat dalam kuesioner.

\section{Pengumpulan Data}

Pengumpulan data pada penelitian ini, dilakukan melalui observasi dan kuisioner.

\section{Analisis Data}

Analisis data dilakukan dengan menggunakan skoring. Terdapat tiga kategori yaitu Baik bila nilai skor yang diperoleh $>75 \%$, Cukup bila nilai yang diperoleh $60 \%-75 \%$, dan Kurang bila nilai skor yang diperoleh $<60 \%$

\section{HASIL DAN PEMBAHASAN Demografi Apotek}

Data demografi apotek Kimia Farma merupakan data dasar untuk mengetahui secara umum profil apotek.. Data tersebut dapat dilihat pada Tabel 1. 
Tabel 1. Distribusi Demografi Apotek

\begin{tabular}{|c|c|c|c|}
\hline NO & Keterangan & $\begin{array}{l}\text { Jumlah } \\
\text { Apotek }\end{array}$ & Persentase \\
\hline \multirow[t]{3}{*}{1} & Lama berdiri apotek & & \\
\hline & $<5$ tahun & 3 & 75 \\
\hline & $\geq 5$ tahun & 1 & 25 \\
\hline \multirow[t]{3}{*}{2} & Lama jam buka & & \\
\hline & $<24$ jam & 3 & 75 \\
\hline & $24 \mathrm{jam}$ & 1 & 25 \\
\hline \multirow[t]{2}{*}{3} & $\begin{array}{l}\text { Omzet penjualan } \\
\text { rata-rata tiap hari }\end{array}$ & & \\
\hline & $<\operatorname{Rp} 5.000 .000$ & 4 & 100 \\
\hline \multirow[t]{5}{*}{4} & $\begin{array}{l}\text { Jumlah resep rata- } \\
\text { rata per hari }\end{array}$ & & \\
\hline & 11-20 lembar & 1 & 25 \\
\hline & 21-30 lembar & 1 & 25 \\
\hline & 31-40 lembar & 1 & 25 \\
\hline & 41-50 lembar & 1 & 25 \\
\hline \multirow[t]{3}{*}{5} & $\begin{array}{l}\text { Jumlah Asisten } \\
\text { Apoteker }\end{array}$ & & \\
\hline & 3-5 orang & 3 & 75 \\
\hline & $>10$ orang & 1 & 25 \\
\hline \multirow[t]{2}{*}{6} & $\begin{array}{l}\text { Lokasi apotek ini } \\
\text { menjadi satu } \\
\text { dengan unit usaha } \\
\text { lain } \\
\text { Ya }\end{array}$ & & \\
\hline & Tidak & 4 & 100 \\
\hline \multirow[t]{3}{*}{7} & $\begin{array}{l}\text { Apotek menjadi } \\
\text { satu lokasi dengan } \\
\text { tempat praktek } \\
\text { dokter }\end{array}$ & & \\
\hline & $\mathrm{Ya}$ & 3 & 75 \\
\hline & Tidak & 1 & 25 \\
\hline \multirow[t]{3}{*}{8} & $\begin{array}{l}\text { Jumlah dokter yang } \\
\text { praktek bersama }\end{array}$ & & \\
\hline & $1-3$ orang & 2 & 50 \\
\hline & $>5$ orang & 1 & 25 \\
\hline
\end{tabular}

Penelitian ini dilakukan untuk mengetahui persentase kesesuaian penerapan standar pelayanan kefarmasian pada 4 Apotek Kimia Farma di Kota Kotamobagu. Hal-hal yang diteliti dalam data dasar apotek ialah lama berdiri, lama jam buka tiap hari, pendapat tiap bulan, jumlah resep rata-rata per hari, jumlah apoteker, lokasi apotek dengan tempat praktek dokter dan jumlah dokter praktek di apotek.

Lama berdirinya suatu apotek tidak mempengaruhi secara langsung terhadap kualitas pelayanan kefarmasian. Pada penelitian ini dapat dilihat gambaran dari pengaruh lamanya berdiri dengan pendapatan dari suatu apotek. Lama berdiri usaha maka akan mempengaruhi tingkat pendapatan, sedangkan lama seorang menekuni usahanya maka akan mempengaruhi prefesionalitas dan akan memiliki semakin banyak relasi bisnis dan pelanggan yang berkunjung. Teori ini juga relevan dengan bidang usaha apotek. Lama berdirinya Apotek dalam penelitian ini dikategorikan menjadi 2 yaitu apotek yang lama berdirinya kurang dari 5 tahun dan lebih dari 5 tahun. Apotek Kimia Farma di Kota Kotamobagu yang memiliki lama berdiri dibawah 5 tahun sebanyak 3 apotek dan hanya 1 apotek yang lama berdirinya diatas 5 tahun.

Kegiatan pelayanan pada apotek Kimia Farma yang telah berdiri lebih dari 5 tahun dilakukan selama 24 jam, sedangkan apotek yang telah berdiri dibawah 5 tahun hanya melakukan kegiatan pelayanan di apotek dibawah 24 jam. Rata-rata pendapatan setiap apotek Kimia Farma di Kota Kotamobagu lebih dari Rp.5.000.000 per hari. Faktor-faktor yang dapat mempengaruhi pendapatan apotek antara lain tingkat kesehatan masyarakat, keadaan sosial dan kebudayaan lokal, pendapatan masyarakat, tingkat pendidikan, kualitas layanan apotek dan lama berdiri dari suatu apotek. Faktor-faktor ini dapat berpengaruh secara langsung pada jumlah resep di apotek setiap hari.

Pelayanan resep setiap hari di apotek Kimia Farma Kota Kotamobagu Apotek A dengan 31-40 lembar, Apotek B dengan 41-50 lembar, Apotek dengan C 21-30 lembar, Apotek D dengan 11-20 lembar. Jumlah resep ini juga dapat dipengaruhi oleh praktek dokter yang berada apotek. Jumlah dokter yang berpraktek berbanding lurus dengan jumlah resep yang dilayani oleh apotek. Semakin banyak dokter yang berpraktek maka jumlah resep akan semakin banyak, demikian sebaliknya. apotek Kimia Farma di Kota Kotamobagu, terdapat 3 apotek yang memiliki dokter praktek dan 1 apotek yang tidak memiliki dokter praktek, sehingga jumlah resep yang dilayani relatif lebih sedikit. Hasil penelitian juga menunjukan bahwa, apotek yang berdiri lebih dari 5 tahun memiliki dokter praktek yang lebih banyak dari pada apotek yang berdiri di bawah 5 tahun. Berdasarkan hal tersebut dapat diketahui pengaruhnya terhadap jumlah penerimaan resep di apotek. 


\section{Demografi Apoteker}

Data demografi apoteker digunakan untuk memberikan gambaran kinerja pelayanan apoteker secara umum yang ada di apotek Kimia Farma di Kota Kotamobagu.

Tabel 2. Distribusi berdasarkan demografi

\begin{tabular}{|c|c|c|c|}
\hline \multicolumn{2}{|c|}{ Apoteker } & \multirow[b]{2}{*}{$\begin{array}{l}\text { Jumlah } \\
\text { Apotek }\end{array}$} & \multirow[b]{2}{*}{ Persentase } \\
\hline No & Keterangan & & \\
\hline 1 & $\begin{array}{l}\text { Pengalaman Apoteker } \\
\text { sebagai Apoteker } \\
\text { Pengelola Apotek } \\
\text { (APA) }\end{array}$ & & \\
\hline & $1-5$ tahun & 2 & 50 \\
\hline & 6-10 tahun & 2 & 50 \\
\hline 2 & $\begin{array}{l}\text { Frekuensi kehadiran } \\
\text { Apoteker di apotek }\end{array}$ & & \\
\hline & Seminggu 3-5 kali & 2 & 50 \\
\hline & Tiap hari & 2 & 50 \\
\hline 3 & $\begin{array}{l}\text { Apoteker tiap kali } \\
\text { datang ke apotek } \\
\text { selama } \\
>5 \text { jam }\end{array}$ & 4 & 100 \\
\hline 4 & $\begin{array}{l}\text { Apakah memiliki } \\
\text { apoteker } \\
\text { pendamping? }\end{array}$ & & \\
\hline & $\mathrm{Ya}$ & 1 & 25 \\
\hline & Tidak & 3 & 75 \\
\hline 5 & $\begin{array}{l}\text { Dalam } 3 \text { tahun } \\
\text { terakhir, kehadiran } \\
\text { dalam mengikuti } \\
\text { pelatihan yang } \\
\text { berhubungan dengan } \\
\text { pendidikan } \\
\text { berkelanjutan tentang } \\
\text { apotek } \\
>3 \text { kali }\end{array}$ & 4 & 100 \\
\hline 6 & $\begin{array}{l}\text { Apakah apoteker sudah } \\
\text { mengetahui tentang } \\
\text { Keputusan Menteri } \\
\text { Kesehatan Republik } \\
\text { Indonesia No } 73 \\
\text { Tahun } 2016 \text { tentang } \\
\text { standar pelayanan } \\
\text { kefarmasian }\end{array}$ & & \\
\hline & Ya & 4 & 100 \\
\hline
\end{tabular}

Apoteker yang memiliki pengalaman kerja sebagai Apoteker Pengelola Apotek (APA) selama 1-5 tahun terdapat pada 2 apotek dan apoteker pada 2 apotek lainnya memiliki pengalaman kerja sebagai APA selama 6-10 tahun. Pengalaman kerja seseorang akan berpengaruh terhadap kinerja, namun dalam penelitian ini tidak dilakukan pengukuran secara spesifik tentang kinerja apoteker. Pada penelitian ini juga dilakukan pengambilan data tentang frekuensi kehadiran apoteker pada ke 4 Apotek Kimia Farma di Kota Kotamobagu. Berdasarkan hasil yang diperoleh, diketahui bahwa sebanyak 50\% APA hadir 3-5 kali dalam seminggu dan $50 \%$ hadir setiap hari. Beberapa aspek atau dimensi untuk mengukur kualitas bidang jasa, termasuk pelayanan apotek yaitu: 1) dimensi tangible (sarana fisik, perlengkapan, pegawai dan lain-lain), 2) dimensi reliability (keandalan), 3) dimensi responsiveness (ketanggapan), 4) dimensi assurance (keyakinan/ jaminan) dan 5) dimensi empathy (perhatian untuk memahami kebutuhan pelanggan). Apabila konsumen apotek puas terhadap pelayanan yang diberikan maka konsumen akan mempunyai persepsi yang baik. Semakin tinggi frekuensi kehadiran dari APA maka akan semakin baik pula pelayanan di Apotek (Handayani, 2016).

Semua apoteker datang melakukan pelayanan kefarmasian di apotek selama lebih dari 5 jam setiap harinya. Kondisi ini menggambarkan bahwa waktu lama pelayanan yang dilakukan oleh apoteker, ketentuan aturan yang dikeluarkan dari apotek Kima Farma yaitu minimal 7 jam setiap harinya. Kehadiran APA selama apotek beroperasi merupakan hal yang harus dipenuhi sesuai dengan standar pelayanan kefarmasian di apotek. Salah satu upaya implementasi penerapan standar pelayanan kefarmasian di apotek secara optimal maka untuk menghadirkan apoteker selama jam buka apotek dapat dilakukan dengan merekrut tenaga apoteker pendamping. Namun pada data yang ditemukan menunjukan bahwa 3 apotek belum memiliki apoteker pendamping, sehingga pada jam-jam tertentu selama apotek beroperasi tidak terdapat apoteker. Akan tetapi, berdasarkan hasil wawancara diketahui bahwa ketika APA tidak berada di tempat maka tugasnya dibantu oleh Asisten Apoteker.

Hasil penelitian menunjukkan bahwa semua APA di Apotek Kimia Farma Kotamobagu sudah mengikuti pelatihan teknis kefarmasian dalam 3 tahun terakhir. Adapun jenis pelatihan yang telah diikuti yaitu pelatihan tentang teknik peracikan obat. Pelatihan yang telah diikuti mengacu pada ruang lingkup pekerjaan kefarmasian yang diatur dalam Peraturan Pemerintah Nomor 51 Tahun 2009. 


\section{Pengelolaan Sumber Daya}

\section{Sumber Daya Manusia}

Sumber daya manusia merupakan salah satu unsur penting yang dipersyaratkan untuk operasional apotek. Berhubungan dengan hal tersebut, maka dalam penelitian ini dilakukan pengumpulan data terkait sumber daya manusia.

Tabel 3. Tabel Distribusi Responden Berdasarkan Sumber Daya Manusia

\begin{tabular}{cccc}
\hline No & Keterangan & $\begin{array}{c}\text { Jumlah } \\
\text { Apotek }\end{array}$ & $\begin{array}{c}\text { Persentase } \\
(\mathbf{\%})\end{array}$ \\
\hline 1 & $\begin{array}{c}\text { Kehadiran Apoteker } \\
\text { di apotek }\end{array}$ & & \\
& $\begin{array}{l}\text { Selama apotek buka } \\
\text { Setiap hari pada jam } \\
\text { tertentu }\end{array}$ & 2 & 50 \\
2 & 2 & 50 \\
& $\begin{array}{l}\text { Apoteker pernah } \\
\text { mengikuti pelatihan } \\
\text { teknis kefarmasian } \\
(3 \text { tahun terakhir) }\end{array}$ & & 100 \\
\hline
\end{tabular}

Berdasarkan hasil penelitian ini diketahui bahwa 2 apotek yang apotekernya hadir setiap hari pada jam tertentu dan 2 apotek dengan kehadiran apoteker yang tidak hadir setiap hari. Hal ini sejalan dengan penelitian yang dilakukan oleh Supardi tentang Standar Pelayanan Kefarmasian dibeberapa apotek Kota Indonesia. Hasil penelitian ini memaparkan bahwa seorang apoteker belum bekerja sepenuh waktu di apotek dikarenakan beberapa hal, antara lain apoteker memiliki pekerjaan lain selain sebagai apoteker di apotek tersebut, kurang patuh terhadap aturan yang termuat dalam Permenkes No.73 tahun 2016, serta adanya pemikiran bahwa kerja di apotek terkesan santai dan tidak membutuhkan jam kerja yang banyak dengan jadwal kunjungan yang tidak menentu. Kehadiran APA selama apotek beroperasi merupakan hal yang harus dipenuhi agar sesuai dengan standar pelayanan kefarmasian apotek (Supardi,2019).

Berdasarkan hasil penelitian menunjukan bahwa semua apoteker yang ada di Apotek Kimia Farma Kota Kotamobagu dalam 3 tahun terakhir telah mengikuti pelatihan teknis kefarmasian. Hal ini menunjukan bahwa setiapa apoteker yang mengikuti pelatihan dapat mampu meningkatkan kemampuan apoteker melakukakn tugasnya dalam pelayanan kefarmasian yang berorientasi kepada pasien dan meningkatkan kesadaran apoteker untuk menjalankan profesinya dengan baik. Selain itu dengan mengikuti pelatihan dalam 3 tahun terakhir, apoteker akan terus memperbaharui pengetahuannya dalam bidang farmasi.

\section{Sarana dan Prasarana}

Saran dan prasarana dalam peningkatan pelayanan kefarmasian, memiliki kegunaan untuk menjamin mutu sediaan farmasi serta kelancaran praktik pelayanan kefarmasian. Pentingnya kegunaan dari sarana dan prasaran sehingga dilakukan pengambilan data.

Tabel 4. Tabel Distribusi Responden Berdasarkan Sarana dan Prasarana

\begin{tabular}{cccc}
\hline No & \multicolumn{1}{c}{ Keterangan } & $\begin{array}{c}\text { Jumlah } \\
\text { Apotek }\end{array}$ & Persentase \\
\hline 1 & $\begin{array}{l}\text { Ruang penyimpanan, } \\
\text { peracikan, dan tempat } \\
\text { penyerahan obat }\end{array}$ & 4 & 100 \\
2 & 3 & 75 \\
$\begin{array}{l}\text { Ruang untuk } \\
\text { pelayanan informasi } \\
\text { obat atau konseling }\end{array}$ & & \\
\hline
\end{tabular}

Sarana dan prasarana di rancang dan di atur untuk menjamin keselamatan dan efisiensi kerja serta menghindari terjadinya keruskan sediaan farmasi. Sarana dan prasarana yang harus di miliki oleh apotek untuk meningkatkan suatu kualitas pelayanan salah satunya memiliki ruang tunggu, tempat penyimpanan dan peracikan, tempat penyerahan resep, serta ruang untuk memberikan informasi obat atau konseling kepada pasien. Hasil penelitian menunjukan bahwa semua Apotek Kimia Farma di Kota Kotamobagu memiliki ruang penyimpanan, peracikan, dan tempat penyerahan resep. Sebanyak 3 Apotek yang memiliki ruangan untuk konseling dengan pasien.

\section{Pengelolaan Sediaan Farmasi dan Perbekalan Kesehatan}

Pengelolaan sediaan farmasi dan perbekalan kesehatan merupakan kegiatan yang menunjang dalam peningkatan pelayanan kefarmasian di Apotek. Sehingga diperlukan untuk mengetahui data dari pengelolaan sediaan farmasi serta perbekalan kesehatan. 
Tabel 5. Tabel Distribusi Responden Berdasarkan Pengelolaan Sediaan Farmasi dan Perbekalan Kesehatan

\begin{tabular}{|c|c|c|c|}
\hline No & Keterangan & $\begin{array}{l}\text { Jumlah } \\
\text { Apotek }\end{array}$ & Persentase \\
\hline 1 & $\begin{array}{l}\text { Perencanaan } \\
\text { pembelian sediaan } \\
\text { farmasi dan } \\
\text { perbekalan kesehatan }\end{array}$ & 4 & 100 \\
\hline 2 & $\begin{array}{l}\text { Pengadaan obat dari } \\
\text { jalur resmi }\end{array}$ & 4 & 100 \\
\hline 3 & $\begin{array}{l}\text { Penyimpanan obat } \\
\text { dalam wadah asli, } \\
\text { pada kondisi yang } \\
\text { sesuai, layak dan } \\
\text { terjamin }\end{array}$ & 4 & 100 \\
\hline 4 & $\begin{array}{l}\text { Pencatatan dan } \\
\text { pengarsipan keluar } \\
\text { masuk sediaan }\end{array}$ & 4 & 100 \\
\hline 5 & $\begin{array}{l}\text { Pencatatan dan } \\
\text { pelaporan narkotika }\end{array}$ & 4 & 100 \\
\hline 6 & Pengarsipan resep & 4 & 100 \\
\hline 7 & $\begin{array}{l}\text { Pemusnahan obat } \\
\text { kadaluarsa atau } \\
\text { narkotika dan } \\
\text { psikotropika oleh } \\
\text { apoteker disaksikan } \\
\text { oleh dinas kesehatan } \\
\text { Kabupaten/Kota }\end{array}$ & 4 & 100 \\
\hline 8 & $\begin{array}{l}\text { Pemusnahan pada } \\
\text { resep yang di simpan } \\
\text { melebihi jangka } \\
\text { waktu } 5 \text { (tahun) }\end{array}$ & 4 & 100 \\
\hline
\end{tabular}

Pengelolaan sediaan farmasi meliputi Perencanaan pembelian perbekalan, Pengadaan obat resmi, Penyimpanan obat, Pencatatan dan Pengarsipan keluar masuk sediaan, pencatatan dan pelaporan narkotika, pengarsipan resep, pemusnahan obat kedaluwarsa atau narkotika dan psikotropika, pemusnahan resep yang melebihi jangka waktu 5 tahun. Hasil yang didapatkan pada semua apotek Kimia Farma di Kotamobagu dikategorikan baik.

Semua apotek Kimia Farma di Kota Kotamobagu memiliki perencanaan dalam pengelolaan sediaan farmasi yang baik. Dalam kegiata perencanaan dilakukan penyusunan kebutuhan obat dengan kriteria yang tepat serta sesuai dengan kebutuhan dan anggaran. Dalam membuat perencanaan sediaan farmasi Kimia Farma di Kotamobagu dilakukan penentuan jumlah barang yang akan di pesan menggunakan analisa EOQ (Economic Order Quantity) dan ROP (Reorder Point).
Pengadaan sediaan farmasi harus dilakukan melalui jalur resmi sesuai ketentuan peraturan perundang-undangan. Hal ini dimaksud untuk menjamin kualitas dari sediaan farmasi. Pengadaan barang baik berupa obat dan perbekalan farmasi dilakukan oleh seorang Asisten Apoteker yang bertanggung jawab kepada APA. Pengadaan barang di apotek Kimia Farma yang ada di Kota Kotamobagu dilakukan melalui Business Manager (BM).

Apotek Kimia Farma di Kota Kotamobagu telah melakukan sistem pencatatan keluar masuk sedian farmasi yang sesuai dengan Permenkes yang berlaku. Pada tahapan pelaporan, setiap apotek Kimia Farma di Kota Kotamobagu melakukan pelaporan dengan membuat laporan stok opname. Laporan stok opname pada apotek Kimia Farma di Kota Kotamobagu dilakukan tiap 3 bulan yaitu pada bulan Maret, Juni, September, dan Desember. Pemeriksaan ini dilakukan untuk mengecek jumlah barang sesuai dengan data dalam kartu stok atau data di komputer.

Kegiatan pengarsipan resep pada semua Apotek Kimia Farma di Kota Kotamobagu telah dilakukan secara rutin. Resep asli dikumpulkan, diurutkan dan disimpan sesuai dengan tanggal penerimaan dan nomor urut resep. Resep dikelompokan dan ditulis keterangan kelompok resep (umum atau narkotika \& psikotropika), tanggal, bulan, dan tahun yang mudah dibaca dan disimpan ditempat yang telah ditentukan. Resep yang diarsipkan pada semua Apotek Kimia Farma di Kota Kotamobagu disimpan dalam lemari/tempat khusus untuk kemudian dimusnahkan setelah melebihi jangka waktu 5 tahun dan dilakukan sesuai dengan peraturan yang berlaku. Selain itu untuk pemusnahan terhadap obat kedaluwarsa atau narkotika dan psikotropika pada semua Apotek Kimia Farma di Kota Kotamobagu dilakukan oleh apoteker disaksikan oleh dinas kesehatan. Pemusnahan yang dilaksanakan sesuai dengan ketentuan peraturan perundang-undangan (Permenkes RI, 2016).

\section{Penilaian Data Pengelolaan Sumber Daya}

Penilaian pengelolaan sumber daya dalam pelayanan kefarmasian sangat diperlukan. Penilaian ini akan menentukan kategori Apotek berdasarkan pengelolaan sumberdaya. 
Tabel 6. Tabel Penilaian Data Pengelolaan Sumber Daya, Sarana dan Prasaran dan Pengeolaan Sediaan Farmasi dan Perbekalan Kesehatan

\begin{tabular}{lll}
\hline $\begin{array}{l}\text { Nama } \\
\text { Apotek }\end{array}$ & Persentase & Kategori \\
\hline Apotek A & $96 \%$ & Baik \\
Apotek B & $96 \%$ & Baik \\
Apotek C & $96 \%$ & Baik \\
Apotek D & $92 \%$ & Baik \\
\hline
\end{tabular}

Penelitian yang dilakukan pada Apotekapotek Kimia Farma di Kota Kotamobagu dalam penilaian data pengelolaan sumber daya semua dikategorikan baik. Apotek A, B, C memiliki persentase $96 \%$ dan Apotek D memiliki persentase $92 \%$. Hasil yang diperoleh ini berdasarkan pada penilaian sumber daya manusia, sarana dan prasaran, pengeolaan sediaan farmasi dan perbekalan kesehatan di apotek.

\subsection{Data Pelayanan Kefarmasian}

\subsubsection{Pelayanan Kefarmasian}

Menurut Permenkes Nomor 73 Tahun 2016 menyatakan pelayanan farmasi klinik di apotek merupakan bagian dari Pelayanan Kefarmasian. Pentingnya pelaksanaan hal ini di Apotek, sehingga perlu diketahui data-data terkait pelayanan farmasi klinik.

Tabel 7. Tabel Distribusi Responden Berdasarkan Pelayanan Kefarmasian

\begin{tabular}{|c|c|c|c|}
\hline No & Keterangan & $\begin{array}{c}\text { Jumlah } \\
\text { Apotek }\end{array}$ & Persentase \\
\hline 1 & $\begin{array}{l}\text { Peracikan, } \\
\text { menimbang, } \\
\text { mencampur, } \\
\text { mengemas, dan } \\
\text { memberi etiket pada } \\
\text { wadah dengan } \\
\text { memperhatikan dosis, } \\
\text { jenis dan jumlah obat }\end{array}$ & 4 & 100 \\
\hline 2 & $\begin{array}{l}\text { Tulisan etiket lengkap, } \\
\text { jelas dan mudah } \\
\text { terbaca }\end{array}$ & 4 & 100 \\
\hline 3 & $\begin{array}{l}\text { Obat di kemasi dengan } \\
\text { rapih dalam kemasan } \\
\text { sehingga terjaga } \\
\text { kualitasnya }\end{array}$ & 4 & 100 \\
\hline
\end{tabular}

4 Penyerahan obat di

4

dahului dengan

pemeriksaan ulang

5 Informasi obat yang di

berikan kepada pasien

meliputi :

Cara pemakaian

Cara penyampaian

obat

Jangka waktu

pengobatan

Aktivitas

Makanan dan

minuman yang harus

di hindari

Efek samping yang

mungkin timbul

6 Pelayanan Informasi

obat :

Aktif (memberi

informasi langsung)

Pasif (Poster, bulletin,

brosur, leflet)

7 Konseling terutama

untuk penyakit kronik

8 Monitoring

penggunaan obat

terutama untuk

penyakit kronik

$9 \quad$ Edukasi tentang

swamedikasi kepada

masyarakat

10 Home Care pada

pasien tertentu

Pelayanan kefarmasian pada Apotekapotek Kimia Farma di Kota Kotamobagu dikategorikan baik. Hampir semua komponen persyaratan dalam pelayanan kefarmasian dapat dipenuhi oleh tiap apotek Kimia Farma di Kota Kotamobagu. Menurut Permenkes Nomor 73 Tahun 2016 menyatakan pelayanan farmasi klinik di apotek merupakan bagian dari Pelayanan Kefarmasian. Pelayanan farmasi klinik ini meliputi pengkajian dan pelayanan resep, dispensing, pelayanan informasi obat (PIO), konseling, pelayanan kefarmasian di rumah (home pharmacy care), pemantauan terapi obat (PTO ).

Kegiatan pengkajian dan pelayanan resep pada Apotek-apotek Kimia Farma di Kota Kotamobagu meliputi administrasi, kesesuaian farmasetik dan pertimbangan klinis. Apotek Kimia Farma di Kota Kotamobagu melakukan tahapan pengkajian resep mulai dari administrasi yang meliputi nama pasien, umur, jenis kelamin, nama dokter, nomor Surat Izin Praktek (SIP), alamat, 
nomor telepon dan tanggal. Pada pengkajian resep apotek Kimia Farma di Kota Kotamobagu melakukan kajian terhadap kesesuaian farmasetik dan pertimbangan klinis seperti ketepatan indikasi dan dosis obat, aturan, cara penggunaan, lama penggunaan obat, dan kontraksi indikasi. Pada setiap tahapan alur pelayanan resep dilakukan upaya pencegahan terjadinya kesalahan pemberian obat (medication error). Apabila dalam pengkajian resep di temukan adanya ketidaksesuain dari hasil pengkajian maka apoteker harus menghubungi dokter penulis resep.

Tahapan selanjutnya dari pelayanan farmasi klinik sesudah dilakukan pengkajian ialah dispensing. Hasil penelitian pada Apotek-apotek Kimia Farma di Kota Kotamobagu terdapat semua apotek melaksanakan setiap tahapan alur dispensing. Adapun alur yang dilakukan oleh semua Apotek Kimia Farma di Kota Kotamobagu yaitu tulisan etiket lengkap jelas dan mudah terbaca, obat dalam kemasan yang rapih, sebelum penyerahan obat dilakukan pemeriksaan ulang. Pada saat dilakukan penyerahan obat, tenaga kefarmasian memberikan informasi obat kepada pasien yang meliputi informasi cara pemakaiannya, penyimpanan obat, jangka waktu pengobatan, aktivitas, informasi makanan dan minuman yang harus dihindari serta efek samping yang mungkin timbul. Pada apotek Kimia Farma di Kota Kotamobagu terdapat dua apotek yang tidak memberikan informasi makanan dan minuman yang harus di hindari dan efek samping yang timbul.

Pelayanan informasi obat yang dilakukan oleh apotek-apotek Kimia Farma di Kota Kotamobagu melalui pelayanan informasi obat aktif dengan memberi informasi obat dengan tidak menunggu pertanyaan dari pasien, melainkan secara aktif memberikan informasi obat, misalnya dengan penerbitan brosur. Selain pelayanan informasi obat secara aktif, dilakukan pelayanan informasi obat secara pasif, dimana apoteker memberikan informasi obat sebagai jawaban atas pertanyaan pasien terkait informasi obat yang masih belum dimengerti.

Pelayanan farmasi klinik juga meliputi tahapan konseling.. Penelitian ini menunjukan bahwa pelayanan konseling telah dilakukan pada semua apotek Kimia Farma di Kota Kotamobagu. Pelayanan konseling terutama dilakukan pada pasien yang memiliki penyakit kronik.

\footnotetext{
Pada tahapan pemantuan penggunaan obat hanya dilaksanakan di 3 Apotek Kimia Farma Kota
}

Kotamobagu. Pemantauan yang dilakukan lebih dikhususkan pada pasien yang menggunakan obat terutama untuk penyakit kronik. Apotek-apotek Kimia Farma di Kota Kotamobagu dapat melayani obat non resep.

Persyaratan kunjungan rumah (home care) hanya dilakukan oleh sebagian apotek yaitu sebanyak 50\%. Pelayanan kefarmasian kunjungan rumah hanya dilakukan oleh apotek-apotek yang lama berdirinya kurang dari 5 tahun. Kunjungan rumah merupakan upaya-upaya yang dilakukan apoteker untuk mengatasi ketidak patuhan pasien dalam perawatan obat-obatan jangka waktu lama.

\subsubsection{Penilaian Data Pengelolaan Pelayanan Kefarmasian}

Tabel 8. Tabel Penilaian Data Pelayanan Kefarmasian

\begin{tabular}{lcc}
\hline Nama Apotek & Persentase & Kategori \\
\hline Apotek A & $100 \%$ & Baik \\
Apotek B & $97 \%$ & Baik \\
Apotek C & $100 \%$ & Baik \\
Apotek D & $87 \%$ & Baik \\
\hline
\end{tabular}

Penilaian pada persentase pelayanan kefarmasian atau pelayanan farmasi klinik pada Apotek-apotek Kimia Farma di Kota Kotamobagu dikategorikan baik. Penilaian yang dilakukan menggunakan kuesioner penilaian pelayanan kefarmasian. Standar penilaian pelayanan kefarmasian mengacu pada Permenkes Nomor 73 Tahun 2016. Standar pelayanan kefarmasian yang dinilai dalam penelitian ialah pengkajian dan pelayanan resep, dispensing, pelayanan informasi obat (PIO), konseling, pelayanan kefarmasian di rumah (home pharmacy care), pemantauan terapi obat (PTO ). Perolehan persentase dari setiap Apotek ialah Apotek A dan C memiliki persentase $100 \%$, Apotek B memiliki persentase $97 \%$ dan Apotek D memiliki persentase $87 \%$. Berdasarkan penilaian yang dilakukan dalam penelitian ini semua Apotek Kimia Farma di Kota Kotamobagu memiliki skor diatas $75 \%$, sehingga dikategorikan baik (Mardiati, 2017).

\section{KESIMPULAN}

Pengelolaan sumber daya dan pelayanan kefarmasian pada semua apotek Kimia Farma di Kota Kotamobagu termasuk dalam kategori baik 


\section{SARAN}

Pengelola apotek Kimia Farma di Kota Kotamobagu tetap terus mempertahankan pengelolaan sumber daya dan pelayanan kefarmasian di apotek. Dapat dilakukan penelitian lebih lanjut untuk menganalisis variabel-variabel yang berpengaruh terhadap pelayanan kefarmasian.

\section{DAFTAR PUSTAKA}

Adelina, G. 2010. Penerapan Standar Pelayanan Kefarmasian Di Apotek Kota Medan, [Skripsi]. Fakultas Farmasi, Universitas Sumatera Utara, Medan.

Anief,M. 2001. Manajemen Farmasi. Universitas Gajah Mada Press, Yogyakarta.

Arikunto,M. 2001. Manajemen Penelitian. Universitas Gajah Mada Press, Yogyakarta.

Badu, N, S 2019. Kesesuaian Penerapan Standar Pelayanan Kefarmasian di Apotek Milik BUMN Wilayah Kota Manado. Pharmacon. 8(3): 695-704.
Diana, K 2019. Pelaksanaan Standar Pelayanan Kefarmasian Di Apotek Kota Palu. AsSyifaa Jurnal Farmasi. 11 (01): 45-54.

Elmiawati, L. 2016. Penerapan Standar Pelayanan Kefarmasian Di Apotek Kota Magelang. Jurnal Farmasi Sains dan Praktis. 2(1). 11-17.

Iman, M. 2019. Metodologi Penelitian Kesehatan. Badan Pengembangan dan Pemberdayaan Sumber Daya Manusia Kesehatan, Jakarta.

Mardiati, N 2017. Pelaksanaan Standar Pelayanan Kefarmasian Apotek Di Wilayah Kota Banjarmasin. Jurnal Borneo Journal of Pharmascientech. 01(01): 37-46.

Notoatmodjo. 2002. Metodologi Penelitian Kesehatan. Rineka Cipta, Jakarta. 